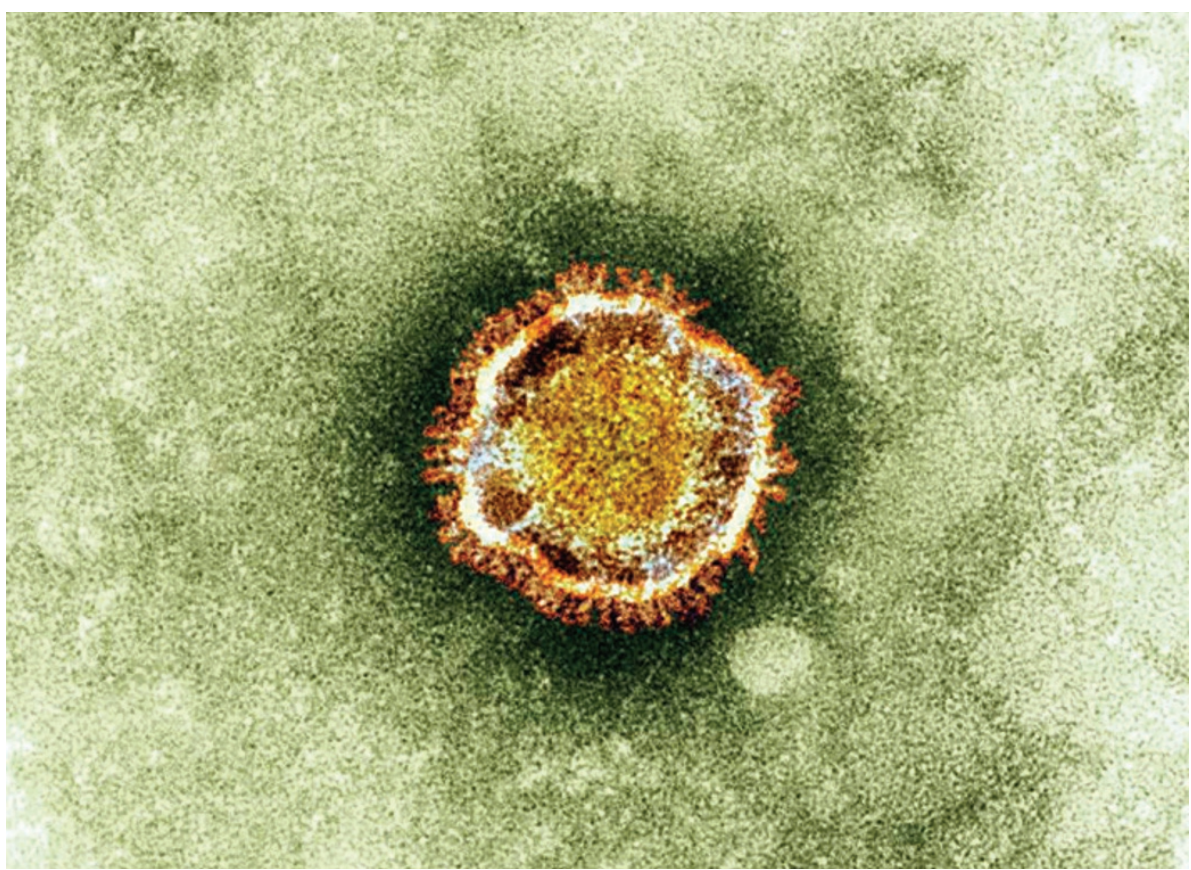

The research legacy of the SARS virus (pictured) is helping scientists to move quickly against a new threat.

BIOMEDICAL RESEARCH

\title{
SARS veterans tackle coronavirus
}

\section{Genome sequence of new virus speeds up testing.}

\section{BY DECLAN BUTLER}

S cientists who helped to fight the 2003 epidemic of SARS (severe acute respiratory syndrome) have sprung into action again to investigate the latest threat: a new SARS-related virus that has killed one man and left another seriously ill. Last week, the researchers reported the genome sequence of the new coronavirus and the first diagnostic tests to screen for it - two major advances that will help in efforts to control the pathogen if it turns into a wider menace.

The SARS virus was identified in March 2003 as the cause of an epidemic that had emerged in China several months before, and which had spread rapidly around the world. It caused nearly 8,500 cases and 916 deaths before it was finally contained in July 2003. At the time, scientists knew almost nothing about the virus - coronaviruses had received scant attention until then because they had previously caused little more than colds.

The research and public-health networks established during the SARS epidemic - and the body of coronavirus research that followed - puts scientists today in a much stronger position to understand the latest virus and to develop countermeasures such as drugs and vaccines, should they be required. "We are all collaborating again," says Christian Drosten, director of the Institute of Virology at the University of Bonn Medical Centre in Germany, who has been involved in developing diagnostic tests for the pathogen. "This is the old SARS club."

So far, there is little evidence that the virus poses any major public-health threat. No one who came into contact with the two cases has fallen ill, suggesting that the virus does not spread easily between humans. Nonetheless, health authorities worldwide are not being complacent - respiratory viruses can cause pandemics, and this strain has already caused serious disease. The key question now, and one that the diagnostics will help to answer, is whether the two cases are isolated events or whether the virus could strike again and perhaps adapt to spread more easily in humans.

The first case was a 60-year-old man admitted to the Dr Soliman Fakeeh Hospital in Jeddah, Saudi Arabia, on 13 June with severe pneumonia and acute renal failure, who died on 24 June. Post-mortem tests were negative for influenza and the other usual suspect viruses, so Ali Mohamed Zaki, a microbiologist at the hospital, ran a coronavirus test at the suggestion of Ron Fouchier, a virologist at Erasmus University Medical Centre in Rotterdam, the Netherlands, who had worked on the SARS virus.

On 20 September, Zaki posted his results on the Program for Monitoring Emerging Diseases (ProMED), an online disease-reporting system, confirming that the coronavirus tests were positive. A week later, Fouchier's group, which had received an isolate of the virus from Zaki in early July, published the pathogen's genome sequence in the GenBank database. The genome confirmed that the pathogen was a new coronavirus, the closest relatives of which are found in bats.

Two days after seeing Zaki's ProMED post, the UK Health Protection Agency reported that it had found a second case: a 49-year-old man from Qatar who fell ill on 3 September with similar symptoms. He was admitted to intensive care in Doha on 7 September and then transferred to a London hospital, where he remains seriously ill. Comparing a fragment of the genome sequence of his virus with that of the first case showed that the two were identical. The viral genome sequence also enabled an international group of researchers, including Fouchier and Drosten, to quickly devise diagnostic tests that look for short, characteristic stretches of the virus's RNA. The collaboration came easily, says Drosten: "The good thing here is that these are all friends from the SARS time."

Existing SARS research provides a useful template for further investigation of this latest coronavirus, adds Drosten. Scientists will use animal models such as mice, ferrets and macaques to study the pathogen's virulence and how it spreads, for example. They will also test whether antivirals and vaccines developed since SARS to treat other coronaviruses are effective.

A key experiment, he says, will be to find where the new virus latches on to the human lung. Some scientists suspect that it might bind to the angiotensin-converting enzyme 2 (ACE2) receptor, as did the SARS virus. That could be both good and bad news. The receptor is found deep in the lungs, where infections can cause severe disease, but viruses nestling there are less apt to be coughed or sneezed into the air than are those found higher in the lungs.

"Receptor-binding properties could also be crucial to the success of potential control measures, should they be needed," says Drosten. SARS was contained by isolating suspected cases, partly because it did not spread quickly, but also because those it infected became very ill before the virus moved into the upper respiratory system. That made cases easy to identify before the patients started spreading the virus. Flu pandemics, by contrast, are impossible to stop, largely because those infected with the virus spread it to others for days before they show any symptoms of infection. 